\title{
Enrichment diets of pigs with oil blends and its effects on performance, carcass characteristics and fatty acid profile
}

\author{
[Dietas enriquecidas com blends de óleos para suínos em terminação e seus efeitos \\ sobre o desempenho, as características de carcaça e o perfil de ácidos graxos] \\ C.S. Souza $a^{1}$ J.A. Moreira ${ }^{2}$, N.R. Silva ${ }^{3}$, A.L. Marinho ${ }^{4 *}$, C.V.S. Costa ${ }^{3}$, \\ J.G. Souza², E.N.M. Teixeira', E.M. Aguiar ${ }^{2}$ \\ ${ }^{1}$ Aluna de pós-graduação - Universidade Federal da Paraíba - João Pessoa, PB \\ ${ }^{2}$ Universidade Federal do Rio Grande do Norte - Natal, RN \\ ${ }^{3}$ Aluno de pós-graduação - Universidade Federal do Rio Grande do Norte - Natal, RN \\ ${ }^{4}$ Pós-doutorado - Bolsista do Programa Nacional CAPES - Universidade Federal do \\ Rio Grande do Norte - Natal, RN
}

\begin{abstract}
The addition of different oil blends in the feed of finishing pigs was evaluated. Twenty-four castrated male finishing pigs were used in a randomized block design containing four treatments and six replicates. The treatments consisted of: Reference ration (RR) - 100\% soybean oil feed; and the combination of the different oils: Blend1 - 50.0\% soybean oil (SO), $25.0 \%$ flaxseed oil (FO), $12.5 \%$ olive oil (OO) and $12.5 \%$ canola oil (CO); Blend2 - 25.0\% SO, 50.0\% FO, $12.5 \%$ OO and 12.5\% CO; and Blend $3-25.0 \%$ SO, $12.5 \% \mathrm{FO}, 12.5 \% \mathrm{OO}$ and $50.0 \% \mathrm{CO}$. The performance, quantitative and qualitative carcass parameters, fatty acids profile and economic feasibility of the diets were evaluated. The use of blends in the diets did not influence the performance or carcass quality, but increased marbling and carcass yield. The fatty acid profile of the loin presented greater amounts of stearic acid in Blend3 and higher percentage of unsaturated fatty acids in animals fed with Blend1. The fatty tissue presented greater amounts of myristic acid in Blend1 and oleic acid in Blend3. The reference ration was the most economic. The Blends did not affect performance or carcass characteristics and improved the fatty acid profile.
\end{abstract}

Keywords: enriched foods, linoleic acid, meat quality, monounsaturated

\section{RESUMO}

Foi avaliada a utilização de diferentes blends de óleo em dietas de suínos em terminação. Foram utilizados 24 suínos, machos, castrados, distribuídos em delineamento de blocos ao acaso, com quatro tratamentos e seis repetições. Os tratamentos consistiram de: ração referência $(R R)-100 \%$ de ração com utilização de óleo de soja; e a combinação de diferentes óleos: Blend1 - 50,0\% de óleo de soja (OS), 25,0\% de óleo de linhaça $(O L), 12,5 \%$ de óleo de oliva $(O O)$ e 12,5\% de óleo de canola $(O C) ;$ Blend2 -25,0\% OS; 50,0\% OL; $12,5 \%$ OO e 12,5\% OC; e Blend 3 -25,0\% OS; 12,5\% OL; 12,5\% OO e 50,0\% OC. Foram avaliados os parâmetros de desempenho, a qualidade de carcaça, o perfil de ácidos graxos e a viabilidade econômica. $O$ uso de blends nas dietas não influenciou o desempenho ou a qualidade da carcaça, mas aumentou o marmoreio e o rendimento de carcaça. O perfil de ácidos graxos do lombo apresentou maiores quantidades de ácido esteárico com a utilização do Blend3 e maior porcentagem de ácidos graxos insaturados nos animais alimentados com o Blend1. O tecido adiposo apresentou maiores quantidades de ácido mirístico quando se forneceu o Blendl e de ácido oleico com o Blend3. A ração testemunha foi a mais econômica. As misturas não afetaram o desempenho e as características de carcaça e melhoraram o perfil de ácidos graxos da carne.

Palavras-chave: alimentos enriquecidos, ácido linoleico, qualidade da carne, monoinsaturados

Recebido em 18 de outubro de 2018

Aceito em 1 de outubro de 2019

*Autor para correspondência (corresponding author)

E-mail: andrezazte@hotmail.com 


\section{INTRODUCTION}

Pig meat has desirable nutritional characteristics such as high protein content and low caloric value, with close to $7 \%$ of total fat (Bragagnolo e Rodriguez-Amaya, 2002). In this sense, there has been an increase of approximately $14 \%$ in the consumption of pig meat in the last decade, which stimulates researchers to invest in the nutritional enriching of this food (Relatório..., 2016).

One of the most used forms to promote change in the lipid profile of meat is the use of oils rich in poly-unsaturated fatty acids (Teye et al., 2006; Realini et al., 2010; Sobol et al., 2016). Palm, fish, sunflower, flaxseed and canola oils are examples tested in pig diets with effects over performance, carcass characteristics and fatty acid composition in the meat. However, they must be added in adequate dietetic proportions for added benefits to the final product.

Saturated fat (C12:0, C14:0 and C16:0) consumption is related to the increase in levels of blood cholesterol for reducing the activity of the LDL-cholesterol receptor thereby decreasing the levels of LDL in the bloodstream. Therefore, the substitution of saturated fatty acids in the diet for mono and polyunsaturated fatty acids by means of the inclusion of oils can be considered an indirect strategy for improving the control of cardiovascular diseases (Grundy and Denke, 1990).

In this context, the objective of this work was to evaluate the addition of different blends of vegetable oils in the feed of finishing pigs over the performance, quantitative and qualitative carcass parameters, fatty acid profile and economic feasibility.

\section{MATERIALS AND METHODS}

All experimental protocols and procedures were approved by the Ethics Committee in Animal Experimentation (Portuguese acronym: CEUA) (protocol number 019/2015-CEUA/UFRN). The animals were allocated into an experimental shed with concrete flooring, containing simple feeding troughs and pacifier type water fountains.
Minimum and maximum thermometers were placed in the interior of the shed for daily registration of temperatures throughout the experimental period. The average minimum and maximum temperatures of the period were 22.3 and $32.4^{\circ} \mathrm{C}$, respectively, and the average relative humidity was of $87.8 \%$.

Twenty-four castrated hybrid male pigs with initial weight of $72.00 \pm 3.4 \mathrm{~kg} / \mathrm{LW}$ were distributed in a randomized block design with four treatments and six replicates. The experimental diets were formulated based on corn, soybean bran, wheat bran and commercial core, supplied with different types of vegetable oils to meet the nutritional demands established by the Brazilian poultry and pork tables (Rostagno et al., 2011) (Table 1). The treatments were constituted by the supplementation of $2 \%$ of the total ingredients in diets and by different types of oils, with $\mathrm{T} 1$ $100 \%$ of soybean oil; T2 - Blend 1: $50 \%$ of soybean oil, $25 \%$ flaxseed oil, $12.5 \%$ olive oil and $12.5 \%$ canola oil; $\mathrm{T} 3$ - Blend 2: $25 \%$ soybean oil, $50 \%$ flaxseed oil, $12.5 \%$ olive oil and $12.5 \%$ canola oil; T4 - Blend 3: 25\% soybean oil, $12.5 \%$ flaxseed oil, $12.5 \%$ olive oil and $50 \%$ canola oil.

During the experimental period, animals received feed and water ad libitum, and the feeds were periodically weighed. The leftovers were weighed to determine the daily feed consumption. The animals were weighed at the beginning and end of the experiment to calculate weight gain and food conversion. When reaching the average weight of $100.00 \pm 6.28 \mathrm{~kg} / \mathrm{LW}$, the animals were led to slaughter. The pigs remained in fasting of solid food for 12 hours and were slaughtered after electric stunning, posteriorly bled, scalded, depilated and eviscerated.

At the end of the slaughter line, the carcasses were identified and weighed for obtaining the warm carcass weight and calculating carcass yield. The initial $\mathrm{pH}$ of the Longissimus dorsi muscle was measured using a digital pachymeter with insertion electrode. The carcasses were separated in two by a longitudinal cut at the lumbar spine and placed in cold chamber at the temperature of $4^{\circ} \mathrm{C}$ for 24 hours. 
Table 1. Food and nutritional composition of the experimental feeds

\begin{tabular}{|c|c|c|c|c|}
\hline \multirow{2}{*}{ Ingredients (\%) } & \multicolumn{4}{|l|}{ Treatments } \\
\hline & Soybean oil & Blend 1 & Blend 2 & Blend 3 \\
\hline Corn & 73.152 & 73.152 & 73.152 & 73.152 \\
\hline Soybean meal & 15.130 & 15.130 & 15.130 & 15.130 \\
\hline Wheat bran & 6.455 & 6.455 & 6.455 & 6.455 \\
\hline Commercial supplement (evimix) ${ }^{1}$ & 3.000 & 3.000 & 3.000 & 3.000 \\
\hline Soybean oil & 2.000 & 1.000 & 0.500 & 0.500 \\
\hline Flaxseed oil & - & 0.500 & 1.000 & 0.250 \\
\hline Olive oil & - & 0.250 & 0.250 & 0.250 \\
\hline Canola oil & - & 0.250 & 0.250 & 1.000 \\
\hline HCL-Lysine & 0.219 & 0.219 & 0.219 & 0.219 \\
\hline L-Threonine & 0.043 & 0.043 & 0.043 & 0.043 \\
\hline Total & 100 & 100 & 100 & 100 \\
\hline \multicolumn{5}{|l|}{ Calculated composition } \\
\hline Metabolizable energy $\left(\mathrm{kcal} \mathrm{kg}^{-1}\right)$ & 3.241 & 3.241 & 3.241 & 3.241 \\
\hline Crude protein $(\%)$ & 13.532 & 13.532 & 13.532 & 13.532 \\
\hline Available phosphorus (\%) & 0.106 & 0.106 & 0.106 & 0.106 \\
\hline Digestible methionine (\%) & 0.232 & 0.232 & 0.232 & 0.232 \\
\hline Digestible lysine $(\%)$ & 0.718 & 0.718 & 0.718 & 0.718 \\
\hline Digestible threonine (\%) & 0.481 & 0.481 & 0.481 & 0.481 \\
\hline Sodium $(\%)$ & 0.154 & 0.154 & 0.154 & 0.154 \\
\hline Chlorine $(\%)$ & 0.042 & 0.042 & 0.042 & 0.042 \\
\hline
\end{tabular}

${ }^{1}$ Guaranteed levels per kg of product: calcium (min) 235g/kg; calcium (max) 240g/kg; phosphorus (min) 34.67g/kg; sodium (min) $585 \mathrm{~g} / \mathrm{kg}$; iron $(\mathrm{min}) 3.389 \mathrm{mg} / \mathrm{kg}$; copper $(\mathrm{min}) 4.000 \mathrm{mg} / \mathrm{kg}$; manganese $(\mathrm{min}) 1.333 \mathrm{mg} / \mathrm{kg}$; zinc $(\mathrm{min})$ $3.333 \mathrm{mg} / \mathrm{kg}$; iodine $(\mathrm{min}) 33.33 \mathrm{mg} / \mathrm{kg}$; cobalt $(\mathrm{min}) 6.86 \mathrm{mg} / \mathrm{kg}$; selenium $(\mathrm{min}) 10 \mathrm{mg} / \mathrm{kg}$; vitamin A (min) 116.800ui/kg; vitamin D3 (min) 25.000ui/kg; vitamin E (min) 833.33ui/kg; vitamin K3 (min) 40mg/kg; vitamin B1 (min) $16.7 \mathrm{mg} / \mathrm{kg}$; vitamin B2 $(\mathrm{min}) 66.7 \mathrm{mg} / \mathrm{kg}$; niacin $(\min ) 500 \mathrm{mg} / \mathrm{kg}$; pantothenic acid $(\mathrm{min}) 267 \mathrm{mg} / \mathrm{kg}$; vitamin B6 (min) $16.7 \mathrm{mg} / \mathrm{kg}$; folic acid (min) $5 \mathrm{mg} / \mathrm{kg}$; biotin $(\mathrm{min}) 3.33 \mathrm{mg} / \mathrm{kg}$; vitamin B12 (min) $333 \mathrm{mcg} / \mathrm{kg}$; phytase $16.66 \mathrm{ftu} / \mathrm{g}$; bht $133 \mathrm{mg} / \mathrm{kg}$; bacitracin (min) $1.883 \mathrm{mg} / \mathrm{kg}$; choline (min) $3.338 \mathrm{mg} / \mathrm{kg}$ and fluor (max) $332 \mathrm{mg} / \mathrm{kg}$.

Subsequently, the carcasses were weighed for obtaining the cold carcass weight and determining the water loss during refrigeration, performing the reading of the final $\mathrm{pH}$, and measuring the carcass length from the cranial edge of the pubic symphysis until the cranio-ventral edge of the atlas with a measuring tape, according to the Brazilian Carcass Classification Method (Bridi and Silva, 2009).

The remaining evaluations were conducted on the left half of the carcass, where a cut was made on point P2 (correspondent to the perpendicular projection of the last rib $4 \mathrm{~cm}$ from the spine) to expose the Longissimus dorsi muscle and the fat layer in order to measure its thickness at this point (at $6.5 \mathrm{~cm}$ from the dorsal line), the Longissimus dorsi muscle depth, using a pachymeter, and of the rib eye and fat area, designed in tracing paper by planimeter and expressed in millimeters. The meat:fat relation was calculated according to technique designed by Bridi and Silva (2009). The back thickness was measured in three points of the carcass: at the height of the first rib, at the last rib and between the last and the second-to-last lumbar by using a pachymeter.

With data of loin depth (LD), backfat thickness (P2), warm carcass weight (WCW), and cold carcass weight $(\mathrm{CCW})$, it was possible to calculate the amount of cooled meat ([7.38- $(0.48 \times \mathrm{P} 2)+$ $0.059 \times \mathrm{LW})+0.525 \times \mathrm{WCW})])$, meat yield ([60$(\mathrm{P} 2 \times 0.58)+(\mathrm{LW} \times 0.10)])$, meat yield in cold carcass $(65.92-\{0.685 \times \mathrm{P} 2)+(0.094 \times \mathrm{LW})-$ $(0.026 \times \mathrm{CCW})])$ and the amount of meat in the carcass (CCW $\mathrm{x}$ meat yield), according to methodology described by Bridi and Silva (2009). For qualitative parameter analyzes, in addition to $\mathrm{pH}$ parameters, the coloration and marbling of the muscle were evaluated, according to the Brazilian Method of Carcass Classification (Método..., 1973; Bridi and Silva, 2009).

The muscle pigmentation was determined using a panel of colors in a scale from one to six of the National Pork Producers Council (Pork..., 1998), 
where 1 represents meats with low pigmentation, and value 6 represents high pigmentation. Marbling was evaluated by using the marbling scale which ranges from 1 to 7 . Meats with value 1 present only traces of marbling, while meat with value 7 presents excessive marbling (Meat..., 2001). Samples of loin and fat were collected, identified and forwarded to the Animal Nutrition Laboratory for evaluating the fatty acid profile of these samples.

The analysis of the fatty acid profile of the fat tissue and loin (Longissimus dorsi) was performed according to methodology proposed by Bligh and Dyer (1959). A mixture containing 5g of moist and shredded fat sample, $12.5 \mathrm{~mL}$ of chloroform and $12.5 \mathrm{~mL}$ of methanol was homogenized in a shaker table for 20 minutes and subsequently left to repose in freezer for 16 hours at $-19^{\circ} \mathrm{C}$. Then, the mixture was filtered with filter paper and transferred to a separation funnel of $250 \mathrm{~mL}$, later were added $12.5 \mathrm{~mL}$ of chloroform and $12.5 \mathrm{~mL}$ of $2 \%$ sodium sulphate solution. The mixture was vigorously agitated and left in repose for two hours.

A biphasic system was formed and its inferior phase with purified lipids was diluted in chloroform and filtered with filter paper containing anhydrous sodium sulphate. Samples were stored in amber flask and frozen at $-20^{\circ} \mathrm{C}$ until the moment of esterification. After extraction, the material was saponified and underwent methylation according to the methodology proposed by Hartman and Lago (1973).

The obtained material underwent gas chromatography (Thermo Scientific - GC/FIDFOCUS) with a flame ionization detector (FID) and Supelco SPTM SP ${ }^{\mathrm{TM}}-2560$ capillary column $(100 \mathrm{~m} \times 0.25 \mathrm{~mm} \times 0.2 \mu \mathrm{m})$. The temperatures of the detector and injector were $270^{\circ} \mathrm{C}$ and $230^{\circ} \mathrm{C}$, respectively. The programming of the column heating was initiated with $40^{\circ} \mathrm{C}$ for three minutes, followed by $180^{\circ} \mathrm{C}$ for five minutes at a rate of $10^{\circ} \mathrm{C} /$ minute, $180^{\circ} \mathrm{C}$ to $220^{\circ} \mathrm{C}$ for three minutes at a rate of $10^{\circ} \mathrm{C} /$ minute, $220^{\circ} \mathrm{C}$ to $240^{\circ} \mathrm{C}$ for 25 minutes at a rate of $20^{\circ} \mathrm{C} /$ minute. The injection volume was of $1 \mu \mathrm{L}$ with Split ratio of $1: 10$. Nitrogen was used as carrier gas. The identification and quantification of spikes was done by comparing the retention time and the area of spikes of samples with those of fatty acid metallic ester patterns (Supelco 37 components FAME Mix, ref. 47885-U).

The economic feasibility of the use of oil blends in the feed of finishing pigs was determined according to Bellaver et al. (1985), where:

Feed Cost $(\mathrm{kg})=$ Feed consumption $\mathrm{x}$ Price per Kg of feed Weight gain

The calculations of Economic Efficiency Index (EEI) and average cost index (CI) were performed according to Barbosa et al. (1992), using the following equations:

$$
\mathrm{EEI}=\frac{\mathrm{MCe}}{\mathrm{CTei}} \times 100 \quad \mathrm{CI}=\frac{\mathrm{CTei}}{\mathrm{MCe}} \times 100
$$

In which: $\mathrm{MC} e=$ lowest average cost in feed per kilogram of gained live weight observed between treatments; CTei $=$ average cost of treatment $i$. The prices of ingredients (expressed in $\mathrm{R} \$$ /kilogram) used in the calculation of feed costs were collected in the region of Natal, Rio Grande do Norte, Brazil. A randomized block design was used to control initial differences in weight, which consisted of four treatments and six replications, constituting 24 plots.

The following model was used for this design: Yijk $=\mu+\mathrm{Ti}+\mathrm{Bj}+$ eijk, where Yijk is an observation of the dependent variable $\mathrm{ij} ; \mu$ is the population mean for the variable; $\mathrm{Ti}$ is the treatment effect, as a fixed effect, $\mathrm{Bj}$ is a block effect with in situ animals, as a random effect, and eijk is the random error associated with the observation ij. Analysis of variance was performance using the GLM procedure of the SAS software (Statistical analysis system, version $9.0)$ by considering the $5 \%$ ( $\mathrm{F}$ test $)(\mathrm{P}<0.05)$ as significant. Data considered as statistically significant were compared by the Duncan at 5\% probability level.

\section{RESULTS}

The performance of pigs fed with the different blends of vegetable oils presented no effect ( $P>0.05$ ) between treatments (Table 2). 
Table 2. Daily feed consumption, daily weight gain and food conversion of pigs fed diets containing vegetable oil Blends

\begin{tabular}{llllll}
\hline \multirow{2}{*}{ Variables } & Treatments & & & & \multirow{2}{*}{ CV $(\%)$} \\
\cline { 2 - 5 } & Soybean oil & Blend 1 & Blend 2 & Blend 3 & \\
\hline Initial weight $(\mathrm{kg})$ & 72.33 & 72.33 & 72.16 & 72.00 & 4.85 \\
Final weight $(\mathrm{kg})$ & 109.16 & 105.16 & 105.00 & 106.00 & 5.29 \\
Weight gain $\left(\mathrm{kg} \mathrm{dia}^{-1}\right)$ & 0.94 & 0.84 & 0.84 & 0.87 & 12.77 \\
Feed consumption $\left(\mathrm{kg} \mathrm{dia}^{-1}\right)$ & 2.75 & 2.70 & 2.46 & 2.68 & 9.70 \\
Food conversion $\left(\mathrm{kg} \mathrm{kg}^{-1}\right)$ & 2.92 & 3.21 & 2.93 & 3.08 & 9.87 \\
\hline
\end{tabular}

The parameters of meat quality, $\mathrm{pH}$, muscle coloration, carcass yield, quantity of cold meat and quantity of meat on the carcass were not influenced $(\mathrm{P}>0.05)$ by the blends, as presented in Table 3, except for marbling, which was higher for animals receiving diets containing the blends. This fact suggests that the combinations of oils rich in polyunsaturated fatty acids influenced the deposition of intramuscular fat. The blend did not influence $(\mathrm{P}>0.05)$ carcass parameters such as cold and warm carcass weights, carcass length, backfat thickness, loin depth, shank weight, rib eye area, fat and meat:fat relation.

Table 3. Qualitative and quantitative parameters of pigs fed diets containing vegetable oil blends

\begin{tabular}{|c|c|c|c|c|c|}
\hline \multirow{2}{*}{ Variables } & \multicolumn{4}{|l|}{ Treatments } & \multirow{2}{*}{$\mathrm{CV}(\%)$} \\
\hline & Soybean oil & Blend 1 & Blend 2 & Blend 3 & \\
\hline \multicolumn{6}{|l|}{ Qualitative parameters } \\
\hline $\mathrm{pH}_{45}$ & 6.36 & 6.59 & 6.33 & 6.42 & 3.19 \\
\hline $\mathrm{pH}_{24}$ & 5.41 & 5.45 & 5.45 & 5.43 & 0.88 \\
\hline Coloration & 2.83 & 3.33 & 3.17 & 3.17 & 19.31 \\
\hline Marbling & $1.00^{\mathrm{B}}$ & $2.00^{\mathrm{A}}$ & $2.00^{\mathrm{A}}$ & $1.83^{\mathrm{A}}$ & 35.85 \\
\hline \multicolumn{6}{|l|}{ Quantitative parameters } \\
\hline Warm carcass weight $(\mathrm{kg})$ & 85.28 & 81.60 & 83.20 & 83.11 & 5.22 \\
\hline Cold carcass weight (kg) & 84.31 & 80.90 & 81.51 & 82.28 & 5.54 \\
\hline Quantity of cold carcass $(\mathrm{kg})$ & 51.76 & 49.66 & 50.58 & 50.59 & 4.46 \\
\hline Shank weight $(\mathrm{kg})$ & 13.13 & 12.61 & 12.90 & 12.88 & 5.44 \\
\hline Carcass yield (\%) & $78.08^{\mathrm{AB}}$ & $77.56^{\mathrm{B}}$ & $79.25^{\mathrm{A}}$ & $78.38^{\mathrm{AB}}$ & 1.35 \\
\hline Meat yield (\%) & 60.57 & 60.49 & 60.52 & 60.54 & 0.11 \\
\hline Meat yield in the cold carcass $(\%)$ & 66.37 & 66.15 & 66.24 & 66.32 & 0.51 \\
\hline Weight loss in cooling $(\%)$ & 0.96 & 0.70 & 1.68 & 0.83 & 1.25 \\
\hline Carcass length $(\mathrm{cm})$ & 101.91 & 99.83 & 101.33 & 100.83 & 2.46 \\
\hline Backfat thickness (mm) & 28.18 & 26.60 & 28.50 & 27.88 & 12.98 \\
\hline Backfat thickness P2 (mm) & 16.30 & 19.00 & 17.72 & 16.87 & 28.62 \\
\hline Muscle depth $(\mathrm{cm})$ & 6.66 & 6.07 & 6.28 & 6.35 & 7.57 \\
\hline Rib eye area $\left(\mathrm{cm}^{2}\right)$ & 47.92 & 42.31 & 42.89 & 45.13 & 10.71 \\
\hline Fat area $(\mathrm{cm})$ & 21.33 & 22.09 & 21.98 & 20.83 & 26.15 \\
\hline Carcass:fat relation $\left(\mathrm{cm}^{2}\right)$ & 2.30 & 2.30 & 2.00 & 2.30 & 33.62 \\
\hline
\end{tabular}

Means followed by different letters in the same line statistically differ by the Duncan test at the level of $5 \%$ of significance. $\mathrm{CV}=$ coefficient of variation.

A difference $(\mathrm{P}<0.05)$ was verified in carcass yield, for which the animals fed Blend 2, Blend 3 and the reference diet presented higher yield. The analysis of fatty acids of the loin (Longissimus dorsi) (Table 4) demonstrated that the combination of oil blends did not change the profiles of lauric, myristic, palmitic and palmitoleic acids, but was capable of changing
$(\mathrm{P}<0.05)$ the profile of stearic acid, insofar as the contents of flaxseed and canola oil in the diet increased, and Blend 3 had the highest content in the meat.

The amount of unsaturated fatty acids was also different $(\mathrm{P}<0.05)$ between the studied treatments, with better results found for animals fed Blend 2, 
followed by those fed the reference diet, Blend 3 and Blend 1, respectively. Despite the profile of unsaturated fatty acids having been influenced by the diet, they were uncapable of changing $(\mathrm{P}<0.05)$ the SFA/UFA (saturated/unsaturated fatty acid) relation.

The use of the vegetable oil blends did not alter $(\mathrm{P}>0.05)$ the concentration of fatty acids in the fat, apart from myristic acid (C14:0) and oleic acid (C18:1 n9C), which demonstrated greater deposition in animals fed diets with Blend 1, Blend 3, Blend 2 and reference diet; and Blend 3, Blend 2, Blend 1 and reference diet, respectively. The analysis of the economic feasibility demonstrated difference $(\mathrm{P}<0.05)$ between all analyzed variables of the treatments (Table 5).

Table 4. Fatty acid profile (\%) and saturated/unsaturated fatty acid relation in the loin (Longissimus dorsi) and fat tissue of pigs fed with vegetable oil blends

\begin{tabular}{|c|c|c|c|c|c|}
\hline \multirow{2}{*}{ Variables } & \multicolumn{4}{|l|}{ Treatments } & \multirow{2}{*}{$\mathrm{CV}(\%)$} \\
\hline & Soybean oil & Blend 1 & Blend 2 & Blend 3 & \\
\hline \multicolumn{6}{|l|}{ Loin } \\
\hline C12:0 Lauric & 0.102 & 0.107 & 0.098 & 0.092 & 24.71 \\
\hline C14:0 Myristic & 0.690 & 0.773 & 0.797 & 0.665 & 32.32 \\
\hline C16:0 Palmitic & 20.436 & 20.855 & 20.845 & 21.477 & 7.30 \\
\hline C16:1 Palmitoleic & 1.515 & 1.391 & 1.426 & 1.372 & 26.30 \\
\hline C18:0 Stearic & $10.547^{\mathrm{B}}$ & $10.815^{\mathrm{AB}}$ & $11.414^{\mathrm{AB}}$ & $11.757^{\mathrm{A}}$ & 8.17 \\
\hline C18:1 n9C Oleic & 25.192 & 24.354 & 27.501 & 25.694 & 14.80 \\
\hline C18:1 n9T Elaidic & 0.145 & 0.153 & 0.147 & 0.187 & 31.84 \\
\hline C18:2 n6C Linoleic & 21.824 & 20.606 & 19.986 & 20.151 & 16.45 \\
\hline C18:2 n6T Linolelaidic & 0.146 & 0.145 & 0.40 & 0.163 & 21.30 \\
\hline C18:3 n6 $\gamma$-Linolenic & 0.557 & 0.572 & 0.664 & 0.702 & 28.06 \\
\hline SFA & 30.983 & 32.103 & 32.482 & 33.235 & 6.68 \\
\hline UFA & $48.532^{\mathrm{AB}}$ & $46.046^{\mathrm{A}}$ & $48.752^{\mathrm{B}}$ & $47.112^{\mathrm{AB}}$ & 4.28 \\
\hline SFA/UFA & 1.553 & 1.445 & 1.500 & 1.413 & 7.49 \\
\hline \multicolumn{6}{|l|}{ Fatty tissue } \\
\hline C12:0 Lauric & 0.104 & 0.177 & 0.141 & 0.137 & 59.40 \\
\hline C14:0 Myristic & $1.076^{\mathrm{A}}$ & $1.655^{\mathrm{B}}$ & $1.256^{\mathrm{A}}$ & $1.379^{\mathrm{AB}}$ & 19.49 \\
\hline C16:0 Palmitic & 24.003 & 22.871 & 22.987 & 22.828 & 16.09 \\
\hline C16:1 Palmitoleic & 1.245 & 1.813 & 1.445 & 1.447 & 30.51 \\
\hline C18:0 Stearic & 16.016 & 16.181 & 15.853 & 14.867 & 14.40 \\
\hline C18:1 n9C Oleic & $31.727^{\mathrm{B}}$ & $34.379^{\mathrm{AB}}$ & $35.925^{\mathrm{A}}$ & $38.003^{\mathrm{A}}$ & 9.24 \\
\hline C18:1 n9T Elaidic & 0.194 & 0.162 & 0.147 & 0.143 & 40.73 \\
\hline C18:2 n6C Linoleic & 17.109 & 17.150 & 15.269 & 14.596 & 18.28 \\
\hline C18:2 n6T Linolelaidic & 0.261 & 0.284 & 0.234 & 0.240 & 21.77 \\
\hline C18:3 n6 $\gamma$-Linolenic & 0.557 & 0.572 & 0.664 & 0.702 & 28.17 \\
\hline SFA & 40.838 & 40.707 & 40.096 & 39.075 & 12.04 \\
\hline UFA & 50.081 & 47.827 & 53.810 & 54.219 & 12.63 \\
\hline SFA/UFA & 1.270 & 1.351 & 1.345 & 1.415 & 16.26 \\
\hline
\end{tabular}

Means followed by different letters in the same line statistically differ by the Duncan test at the level of 5\% of significance. $\mathrm{CV}=$ coefficient of variation.

Table 5. Economic evaluation of the pig feeds containing vegetable oils

\begin{tabular}{llllll}
\hline \multirow{2}{*}{ Variables } & Treatments & & & & \multirow{2}{*}{$\mathrm{CV}(\%)$} \\
\cline { 2 - 5 } & Soybean oil & Blend 1 & Blend 2 & Blend 3 & \\
\hline Feed cost $(\mathrm{R} \$ / \mathrm{Kg})$ & $1.83^{\mathrm{C}}$ & $2.86^{\mathrm{AB}}$ & $3.18^{\mathrm{A}}$ & $2.45^{\mathrm{B}}$ & 10.58 \\
Cost index & $100.00^{\mathrm{C}}$ & $156.02^{\mathrm{AB}}$ & $173.46^{\mathrm{A}}$ & $133.66^{\mathrm{B}}$ & 10.57 \\
Economic efficiency index & $101.57^{\mathrm{A}}$ & $65.68^{\mathrm{BC}}$ & $58.25^{\mathrm{C}}$ & $76.03^{\mathrm{B}}$ & 8.84 \\
\hline
\end{tabular}

Means followed by different letters in the same line statistically differ by the Duncan test at the level of $5 \%$ of significance. $\mathrm{CV}=$ coefficient of variation. 


\section{DISCUSSION}

In the performance evaluation, no significant differences were observed between the studied treatments. This may have been because the diets were isonutritive and met the animals' needs. As the feeds were supplemented with oil blends containing different fatty acid concentrations, effects were expected on animal metabolism. According to Campanella et. al 2014, the composition of safflower oil can affect the satiety center and reduce feed intake, but in the studied context, the oil blends did not have this characteristic.

The results obtained in this experiment are in line with studies by Bertol et al. (2013), in which was evaluated the feasibility of using flaxseed and canola oils for the enrichment of pig meat, but no significant differences for performance variables were found. Similarly, Sobol et al. (2016) evaluated diets enriched with a mixture of $2 \%$ flaxseed oil, $0.5 \%$ canola oil and $5 \%$ fish oil for finishing pigs and no significant differences were found either. Santos, et al., 2008 and Murakami, et al., 2014, studied the use of flaxseed oil in pigs feed and observed a reduction in feed intake that was attributed to the possibility of animals' refusal due to the odor and unpleasant taste of the mixture used, but this was not observed in the present study.

In the study of meat quality, an increase in the degree of marbling in the loin of the animals that consumed the oil blends was observed. This can be a result of the enrichment of diets with olive, canola and flaxseed oils, differing from studies developed by Bertol et al. (2013), who studied flaxseed and canola oils and Nuernberg et al. (2005), who evaluated the supplementation of olive oil and flaxseed oil for pigs and found no difference in marbling. The increase of intramuscular fat is extremely important as it improves the juiciness, tenderness and taste of meat (Bridi and Silva, 2009).

The use of oil blends in diets did not affect the carcass characteristics of pigs, as observed by several authors (Teye et al. 2006 and Realini, et al. 2010) who studied the effects of different types of oils on diets and did not observe effects either. Oils may enrich meat with beneficial fatty acids to human health, but may not interfere with animal growth, and this same effect is observed when using oil mixtures.

Regarding carcass yield, the best results were observed for Blends 2 and 3. Blend 1 had the worst results, because nutrient utilization was less efficient, since animals from this treatment presented lower carcass weight and higher thickness of backfat P2 and fat area than animals of different treatments. This showed the oil mixture used for the composition of Blend 1 provided higher fat deposition in the carcass and probably higher organ weight, resulting in lower carcass yield.

Regarding the results obtained in the evaluation of fatty acids, among the saturated, the manipulation of the ratio of oils used promotes the increase of the stearic fatty acid deposition in the loin of pigs fed with the blends. This is a favorable result, since this fatty acid, although saturated, has a neutral action on the animal organism, and is converted to oleic acid by their metabolism. Although stearic acid has a saturated chain, it does not elevate serum cholesterol levels, because dehydrogenation of this fatty acid is faster than chain elongation, thereby making it more rapidly converted to oleic acid in the liver through the enzyme $\Delta^{9}$ desaturase (Martin et al., 2006; Lottenberg, 2009).

Another benefit associated with eating C18:0-rich foods is related to decreased cholesterol absorption. Unlike hypercholesterolemic saturated fatty acids (lauric, myristic and palmitic), C18:0 does not suppress LDL receptors and therefore, does not contribute to the increase in circulating cholesterol content (Schneider, et al., 2000). Jang et al. (2017) evaluated the fat content and fatty acid composition in different cuts of pork and observed a higher concentration of palmitic fatty acids (C16:0), stearic acid (C18:0) and oleic acid (C18:1, n -9) in the loin of evaluated pigs.

Regarding adipose tissue, an increase in oleic fatty acid deposition with the use of blends was observed, proving the best ratio of unsaturated fatty acids in these treatments. The increase in the percentage of oleic acid is related to the higher inclusion of canola oil in Blend $3(50 \%)$, a product rich in polyunsaturated fatty acids with about $61 \%$ of oleic acid in its composition (Johnson, et al.,2007). The incorporation of oleic acid in 
tissues by feed manipulation was also observed by Teye et al. (2006) and Mitchaothai et al. (2007), which corroborates the results of the present study. The authors also reported that dietary manipulation should be encouraged in order to establish the limits of oil inclusion, thereby producing healthier meat. Mas et al. (2011) reported that diets with higher levels of oleic acid present higher proportions of all monounsaturated fatty acids and C18:1 in intramuscular fat compared with basal diets.

As described by Morel et al. (2008), diet composition affects pig meat composition in terms of polyunsaturated fatty acids. Different sources of dietary fat will result in a different fat composition than pork cuts. Continuing the fatty acid profile study, Morel et al. (2013), found that the fatty acid profiles of the loin and backfat were similar to the fatty acid profiles of the diets (tallow and soybean oil + flaxseed oil). The authors reported the direct influence of high fatty acid diets on increasing levels of these fatty acids in pig meat.

In a review of the benefits of canola oil-rich nutrition, Lin et al. (2013), reported that the use of this oil in the feeding of monogastric animals provides significant decrease in total cholesterol and LDL levels and positive actions to increase tocopherol levels, and improve insulin sensitivity. Regarding the economic viability of the feeds used in this experiment, the average cost was higher when offering feeds containing the blends. Blend 1, Blend 2 and Blend 3 increased food costs by $55 \%, 73 \%$ and $33 \%$, respectively, when compared to the reference diet. Blend 2 presented the highest cost, explained by the higher concentration of flaxseed oil in the diet (50\%), since this is the highest value oil.

The best economic results, measured by economic efficiency and cost indices, were obtained with the reference diet, followed by diets containing Blend 3 , Blend 1 and Blend 2. The average cost of flaxseed oil feed negatively impacted the economic efficiency index, and the index improved when its inclusion in the blends decreased. However, the feed costs vary according to the prices of ingredients, which fluctuate throughout the year and may become more affordable at certain times.

\section{CONCLUSION}

The use of blends is recommended because it promotes greater meat marbling, higher carcass yield and loin and backfat enrichment with stearic acid and omega-9, respectively, even though its use has increased the feed costs.

\section{REFERENCES}

BARBOSA, H.P.; FIALHO, E.T.; FERREIRA, A.S. et al. Triguilho para suínos nas fases inicial de crescimento, crescimento e terminação. Rev. Soc. Bras. Zootec. v.21, p.827-837, 1992.

BELLAVER, C.; FIALHO, E.T.; PROTAS, J.F.S. Malt starch in feed for growing and finishing pigs. Pesqu. Agropecu., v.20, p.969-974, 1985.

BERTOL, T.M.; CAMPOS, R.M.; LUDKE, J.V. et al. Effects of genotype and dietary oil suplementation on performance, carcass traits, pork quality and fatty acid composition of backfat and intramuscular fat. Meat Sci., v.93, p.507-516, 2013.

BLIGH, E.C.; DYER, W.J. A rapid method of total lipid. Extraction and purification. Can. J. Biochem. Physiol., v.37, p.911-917, 1959.

BRAGAGNOLO, N.; RODRIGUEZ-AMAYA, D.B. Simultaneous determination of total lipid, cholesterol and fatty acids in meat and backfat of suckling and adult pigs. Food Chem., v.79, p.255260, 2002.

BRIDI, A.M.; SILVA, C.A. Evaluation of pork. Londrina: Midiograf, 2009.

CAMPANELLA, L.C.A.; FREYGANG, J.; DAL MAGRO, D.D. et al. Efeito da suplementação de óleo de cártamo sobre o peso corporal, perfil lipídico, glicídico e antioxidante de ratos wistar induzidos à obesidade. Rev. Ciênc. Farm. Bás. Aplic., v.35, p.141-147, 2014.

GRUNDY, S.M.; DENKE, M.A. Dietary influences on serum lipids and lipoproteins. $J$. Lipid Res., v.31, p.1149-1172, 1990.

HARTMAN, L.; LAGO, B.C.A. A rapid preparation of fatty methyl esters from lipids. $L a b$. Pract., v.22, p.475-477, 1973.

JANG, H.L.; PARK, S.Y.; LEE, J.H. et al. Comparison of fat content and fatty acid composition in different parts of Korean beef and pork. J. Korean Soc. Food Sci. Nutr., v.46, p.703$712,2017$. 
JOHNSON, G.H.; KEAST, D.R.; KRISETHERTON, P.M. Dietary modeling shows that the substitution of canola oil for fats commonly used in the United States would increase compliance with dietary recommendations for fatty acids. J. Am. Diet. Assoc., v.7, p.1726-1734, 2007.

LIN, L.; ALLEMEKINDERS, H.; DANSBY, A. et al. Evidence of health benefits of canola oil. Nutr. Rev., v.71, p.370-385, 2013.

LOTTENBERG, A.M.P. Importância da gordura alimentada na prevenção e no controle de distúrbios metabólicos e da doença cardiovascular. Arq. Bras. Endocrinol. Metabol., v.53, p.595-607, 2009.

MARTIN, C.A.; ALMEIDA, V.V.; RUIZ, M.R. et al. Ácidos graxos poli-insaturados ômega-3 e ômega-6: importância e ocorrência em alimentos. Bra. J. Nutr., v.19, p.761-770, 2006.

MAS, G.; LLAVALL, M.; COLL, D. et al. Effect of an elevated monounsaturated fat diet on pork carcass and meat quality traits and tissue fatty acid composition from York-crossed barrows and gilts. Meat Sci., v.89, p.419-425, 2011.

MEAT evaluation handbook. Savoy, USA: AMSA, 2001. p.86-110.

MÉTODO brasileiro de classificação de carcaças. 2.ed. Rio Grande do Sul: ABCS, 1973. 17p.

MITCHAOTHAI, J.; YUANGKLANG, C.; WITTAYAKUM, S. et al. Effect of dietary fat type on meat quality and fatty acid composition of various tissues in growing-finishing swine. Meat Sci., v.76, p.95-101, 2007.

MOREL, P.C.; LEONG, J.; NUIJTEN, W.G. et al. Effect of lipid type on growth performance, meat quality and the content of long chain n-3 fatty acids in pork meat. Meat Sci., v.95, p.151159,2013

MOREL, P.C.H., JANZ, J.A.M., ZOU, M. et al. The influence of diets supplemented with conjugated linoleic acid, selenium, and vitamin E, with or without animal protein, on the composition of pork from female pigs. J. Anim. Sci., v.86, 1145-1155, 2008.
MURAKAMI, A.E.; EYNG, C.; TORRENT, J. Effects of functional oils on performance, apparent metabolizable energy and intestinal morphometry in broiler chickens. Asian Australas. J. Anim. Sci., v.27, p.981-989, 2014.

NUERMBERG, K.; FISCHER, K.; NUERNBERG, G. et al. Effects of dietary olive and linseed oil on lipid composition, meat quality, sensory characteristics and muscle structure in pigs. Meat Sci., v.70, p.63-74, 2005.

PORK quality targets. Des moines. Washington: NPPC, 1998. p.1-2.

REALINI, C.E.; DURAN-MONTGÉ, P.; LIZARDO, R. Effect of source of dietary fat on pig performance, carcass characteristics and carcass fat content, distribution and fatty acid composition. Meat Sci., v.85, p.606-12, 2010.

RELATÓRIO anual. São Paulo: ABPA, 2016. Disponível em: <http://abpabr.com.br/setores/avicultura/publicacoes/relatori os-anuais/2016>. Acessado em: 3 out. 2016.

ROSTAGNO, H.S.; ALBINO, L.F.T.; DONZELE, J.L. et al. Tabelas brasileira de aves e suínos: composição alimentar e exigências nutricionais. 3.ed. Viçosa: UFV, 2011. 141p.

SANTOS, C.; CAMBERO, M.I.; CABEZA, M.C.; ORDÓNEZ, J.A. Enrichment of dry-cured Ham with $\alpha$-linolenic acid and $\alpha$-tocopherol by the use of linseed oil and $\alpha$-tocopheryl acetate in pig diets. Meat Sci., v.80, p.668-674, 2008.

SCHNEIDER, C.L.; COWLES, R.L.; STUEFERPOWELL, C.L. Dietary stearic acid reduces cholesterol absorption and increases endogenous cholesterol excretion in hamsters fed cereal-based diets. J. Nutr., v.130, p.1232-1238, 2000.

SOBOL, M.; RAJ, S.; SKIBA, G. Effect of fat content in primal cuts of pigs fed diet enriched in n-3 polyunsaturated fatty acids on healthpromoting properties of pork. J. Anim. Feed Sci., v.25, p.20-28, 2016.

TEYE, G.A.; SHEARD, P.R.; WHITTINGTON, F.M. et al. Influence of dietary oils and protein level on pork quality. 1. Effects on muscle fatty acid composition, carcass, meat and eating quality. Meat Sci., v.73, p.157-165, 2006. 